\title{
Regulation of Securitised Products Post the FinANCIAL CRISIS
}

Hans von Reden

\begin{abstract}
Securitisation has been one of the main reasons for the global financial crisis. The securitisation business has experienced a steep decline for two decades until an even stronger decline in the summer of 2007. This article analyses the regulatory developments in the structured market and the measures taken by legislators since the crisis to address the shortcomings in the securitisation market. The main problems are centred around four areas, which are analysed separately: first, misalignment of interests between investors and originators; second, inadequate capital rules failing to reflect the actual risk exposures; third, insufficient disclosure and information overload of investors; and fourth, credit rating agencies failing to give quality ratings. It concludes that while the adopted regulatory measures might have less corrective effects than envisaged, this is favourable as long as the precise consequences of the adopted measures are not clear.
\end{abstract}

\section{A. INTRODUCTION}

Securitisation has been identified as one of the causes that aggravated the 2007-2008 global financial crises (GFC). ${ }^{1}$ It is defined by the Capital Requirements Directive $(\mathrm{CRD})^{2}$ as a transaction tranching the credit risk of an asset exposure. Thereby, it is essential that the payment of the asset exposure determines the payment in the transaction, and that absorption of losses is determined by the subordination structure of the tranches. ${ }^{3}$ Generally, the sponsor will initiate the process, through which the underlying assets are transferred by the originator to a securitisation special purpose entity (SSPE). The SSPE in turn issues different classes of securities in tranches to investors via an underwriter. The success or failure of a security's issuance will largely depend on how a credit rating agency (CRA) has rated each tranche, which reflects the creditworthiness of the underlying assets and the securitisation structure. ${ }^{4}$ Various types of assets such as residential mortgages (residential mortgage-backed securities (RMBS)) or

\footnotetext{
* Market Infrastructure Specialist at the European Central Bank, Target2Securities, and Master of Laws (LLM), University College London. The views expressed in this article are my own. I wish to thank Maximilian Vollmer and Sarah Burke for their comments on an earlier draft.

${ }^{1}$ David Ramos Muñoz 'In praise of small things: securitization and governance structure' (2010) 5(4) CMLR 363, 366.

${ }^{2}$ Council Directive 2006/48/EC of 14 June 2006 relating to the taking up and pursuit of the business of credit institutions, consolidated version [2006] OJ L177/1 (CRD).

${ }^{3}$ CRD, art 4(36).

${ }^{4}$ Ramos Muñoz (n 1) 365.
} 
asset-backed securities (ABS) can be securitised. If the RMBS exposure is securitised multiple times, a more complex product such as collateralised debt obligations (CDO) or CDO squared or cubed is created. ${ }^{5}$

The legislator has taken a piecemeal approach towards the regulatory framework concerning securitisation. ${ }^{6}$ At the international level, non-binding legal rules and principles have been agreed upon by the Basel Committee on Banking Supervision (BCBS), which are then implemented into binding European law. The national legislator needs to transform European directives into national law unless a regulation has been adopted at the European level. Basel I to III contain the BCBS recommendations. ${ }^{7}$ The Capital Requirements Directive (CRD) represents the respective European binding law of Basel I and II and has been amended twice thus far by CRD2 and $3 .^{8}$ Basel III will be implemented under the CRD4 package, the proposal for which is expected to be implemented on 1 January 2014 at the time of writing. It consists of both a directive and a regulation (CRR) ${ }^{9}-$ the singe rule book - which would replace the former CRDs. In the United Kingdom (UK), the Prudential Regulation Authority (PRA) (formerly Financial Services Authority, FSA) transforms most of the CRD and its amendments into national law, which it does within its handbook, the Prudential Sourcebook for Banks, Building Societies and Investment Firms (BIPRU). Therein, the PRA has adopted an intelligent copy-out approach, using the

\footnotetext{
${ }^{5}$ For a more detailed explanation of the various securitisation structures, see Steven L Schwarcz 'Disclosure's Failure in the Subprime Mortgage Crisis' (2008) 3 Utah LRev 1109, $1111 \mathrm{f}$.

6 David Ramos Muñoz 'Living on the Edge: Securitization Supervision and Characterization Problems' (2009) 6(5) ECL 217, 211.

${ }^{7}$ Basel I refers to BCBS, 'International convergence of capital measurement and capital standards' (July 1988); Basel II refers to BCBS, 'International Convergence of Capital Measurement and Capital Standards. A Revised Framework. Comprehensive Version' (June 2006).

${ }^{8}$ Council Directive 2006/48/EC of 14 June 2006 relating to the taking up and pursuit of the business of credit institutions, consolidated version [2006] OJ L177/1 (CRD); Council Directive 2009/111/EC of 16 September 2009 amending Directives 2006/48/EC, 2006/49/EC and 2007/64/EC as regards banks affiliated to central institutions, certain own funds items, large exposures, supervisory arrangements, and crisis management [2009] OJ L302/97 (CRD2); Council Directive 2010/76/EU of 24 November 2010 amending Directives 2006/48/EC and 2006/49/EC as regards capital requirements for the trading book and for resecuritisations, and the supervisory review of remuneration policies [2010] OJ L 329/3 (CRD3).

${ }^{9}$ Commission, 'Proposal for a Regulation of the European Parliament and of the Council on Prudential Requirements for Credit Institutions and Investment Firms' COM(2011) 452 final (CRR proposal).
} 
precise wording found in the CRD. Chapter 9 of the BIPRU is the relevant part dealing with securitisation. ${ }^{10}$

The securitisation market has become increasingly developed over the past forty years. By 2011, it had grown to USD7 trillion of US mortgagerelated securities and to over USD2.2 trillion in non-mortgage-related ABS. ${ }^{11}$ This sharp increase is due to the fact that the securitisation process is advantageous for many participants. The traditional banking system was based on an 'originate-to-hold' model (OTH-model). Banks would grant a loan to a borrower, for instance a mortgage, and had to hold it on their balance sheet until it was fully repaid. The drawback of this model was that it caused liquidity shortages in that it prevented banks from further lending owing to capital adequacy requirements introduced by Basel I in $1988 .{ }^{12}$ This liquidity shortage could be tackled by a new innovative process: securitisation. It cleared the banks' balance sheets and provided them with fresh funds, enabling them to grant new loans to borrowers, which were then securitised again. Thus, the originate-to-distribute model (OTD-model) was born, ${ }^{13}$ building the foundations of a long-lasting, ascending and accelerating period of development.

Nevertheless, the rise of this newly established trend cannot solely be attributed to the OTD-model, it is also the result of stakeholders, other than the involved banks, profiting from the structure. From the beginning, the US Government supported securitisation as it provided a mechanism to expand home ownership throughout the country. ${ }^{14}$ For financial institutions, sponsoring securitisation transactions provided a considerable income fee. ${ }^{15}$ More importantly, it allowed them to manage and reduce their own credit risk. ${ }^{16}$ Consequently, banks were now enabled to continue and further increase lending under the capital requirements. ${ }^{17}$ It was also considered

${ }^{10}$ Leonard $\mathrm{Ng}$, 'Changes to Basel II and the EU capital requirements Directive: implications for securitisation' (2010) 25(6) JIBLR 265, 266.

${ }^{11}$ Dan Awrey, 'Complexity, Innovation and the Regulation of Modern Financial Markets' (2011) Oxford Legal Studies Research Paper No. 49/2011, 41, available at http://ssrn.com/abstract=1916649.

12 Jan Job de Vries Robbé, Securitization Law and Practice, In the Face of the Credit Crunch (Kluwer Law International 2008) 406f.

${ }^{13}$ Ramos Muñoz (n 1) 367.

${ }_{15}^{14}$ Awrey (n 11) 42.

${ }^{15}$ Ibid.

${ }^{16}$ Vittoria Cerasi and Jean-Charles Rochet, 'Rethinking the Regulatory Treatment of Securitization' (2011) Paolo Baffi Centre Research Paper No. 2008-21, 2, available at http://ssrn.com/abstract=1170982.

${ }^{17}$ Ibid, p. 3; Awrey (n 11) 42. 
beneficial to manage and overcome liquidity shortages. ${ }^{18}$ Finally, securitisation responded to a growing appetite for risk among investors looking for higher yields, allegedly at low risk, and a diverse investment portfolio. ${ }^{19}$

In a bullish market, those benefits had outweighed the drawbacks; however, in a bearish market, as in the summer of 2007, the drawbacks aggravated and became visible, worsening the financial crisis. Four main shortcomings in the securitisation process have been identified. First, research finds that the OTD-model caused a misalignment of interest between originators and investors. Credit institutions lacked incentives to engage in proper screening of loan-level data and to adhere to thorough underwriting standards. ${ }^{20}$ In contrast, under the traditional OTH-model, banks had sufficient incentives to conduct proper due diligence of its debtors in order to reduce the default rate of their outstanding loans. ${ }^{21}$ Second, regulatory capital requirements did not differentiate between traditional securitisation and more complex resecuritisation products, despite the latters' increased riskiness and need for liquidity. Many financial institutions were exposed to greater credit losses during the GFC than expected. ${ }^{22}$ By holding the positions in the trading instead of the banking book, they could circumvent higher capital requirements, which in turn allowed banks to increase lending and securitisation capacities. ${ }^{23}$ Third, CRAs played a crucial role in the boom of the subprime market as high ratings attracted both regulated and unregulated financial institutions, as well as meant higher profits for sponsors and originators, who could pay lower interests for high rated tranches. ${ }^{24}$ However, they had to downgrade a significant number of

\footnotetext{
${ }^{18}$ Ramos Muñoz (n 6) 217.

${ }^{19}$ Awrey (n 11) 42.

${ }^{20}$ Cerasi (n 16) 2 referring to Sinan A. Cebenoyan and Philip E. Strahan, 'Risk Management, Capital Structure and Lending at Banks' (2004) 28(1) JBF 19; Benedikt Goderis and others, 'Bank Behavior with Access to Credit Risk Transfer Markets' (2006) Tilburg University CentER Discussion Paper No. 100, available at http://econpapers.repec.org/paper/dgrkubcen/2006100.htm; Bernadette A. Minton, René M. Stulz and Rohan M. Williamson, 'How Much Do Banks Use Credit Derivatives to Reduce Risk?' (2006) Fisher College of Business Working Paper No. 2006-03-001, available at http://ssrn.com/abstract $=785364$; Darrell Duffie, 'Innovations in Credit Risk Transfer: Implications for Financial Stability' (2008) BIS Working Paper No. 225, available at http://ssrn.com/abstract $=1165484$.

${ }^{21}$ Ramos Muñoz (n 1) 367.

${ }^{22}$ Cerasi (n 16) 2f.

${ }^{23}$ Awrey (n 11) 42f.

${ }^{24}$ Lawrence J White, 'Credit-Rating Agencies and the Financial Crisis: Less Regulation of CRAs is a Better Response’ (2010) 25(4) JIBLR 170, 174.
} 
investment grade ratings in the aftermath of the crisis, as a result of the rapidly increasing default rates of the higher rated tranches that were considered to be lower risk. This shows that CRAs failed to maintain information symmetry and to give unbiased quality ratings, which is considered to be the result of a mixture of problems: conflict of interests, increasing complexity of (re-)securitised products, and regulatory and investor over-reliance. Fourth, investors failed to perform their role in understanding their investments and assessing the respective creditworthiness themselves. Over-reliance on CRAs can be seen as a cause of negligent behaviour, insufficient loan-level disclosure by originators, and information overload. ${ }^{25}$

Around six years have passed since the GFC broke out in the summer of 2007. Much ink has been spilt over the causes, reasons and shortcomings of the crisis, and the resulting need for regulatory reform. Now, it is time to analyse if and how those shortcomings have been addressed. The objective of this paper is to analyse the current status of regulatory reforms concerning securitised products and to identify the remaining problems that either have not been addressed yet or that emerge as a result of the new measures. To achieve this objective, the four shortcomings identified above will be discussed in separate sections. Part B will discuss the misalignment of interests and risk retention requirements, Part $\mathrm{C}$ the changes in relation to regulatory capital requirements, Part $\mathrm{D}$ the new disclosure, transparency and standardisation requirements, and Part $\mathrm{E}$ the legislation addressing the shortcomings regarding the failures of the CRAs. Within each section, the problems as they materialised in the GFC will be described and the main scholarly debate will be presented. Against this background, the regulatory solutions will be analysed so that the shortcomings of the current regulatory approach can be identified.

\section{B. ALIGNMENT OF INCENTIVES AND RISK RETENTION}

The advantage of securitisation, allowing the originator to transfer its credit risk exposure to investors willing to invest in the credit risk, has turned into a disadvantage in that it has led to some originators adopting lower screening and underwriting standards towards the underlying assets. The underlying rationale of this deficiency has been that the interests of originators and investors were not properly aligned. The former had little interest in

${ }^{25}$ Awrey (n 11) 43. 
investing efforts into proper due diligence, knowing it would transfer the credit risk exposure to the latter, which in turn possessed insufficient information and control about the process and underlying loan portfolio. This so called originate to distribute model (OTD-model) created a moral hazard problem and the misalignment of interests between originators and investors was identified as one of the shortcomings of the securitisation process. $^{26}$

Any regulatory solution will have to strike a balance between the parties' interests: the investor wants to be sure that the originator has undertaken proper due diligence concerning the underlying assets and therefore needs to be in a position to assess the originator's efforts; ${ }^{27}$ the originator wants to be able to transfer and diversify its risk exposure and raise new finances. ${ }^{28}$ Thus, the objective is to align these two interests.

\section{Retention level}

To align the investors' and originators' interests, the European Commission (hereafter: Commission) has suggested that the OTD-model is constrained by restricting the originator to fully transfer its credit risk exposure. It is supposed to retain a nominal exposure of five percent, ${ }^{29}$ which is referred to as 'skin-in-the-game' approach. ${ }^{30} \mathrm{CRD} 2$ introduced the retention requirement at European level in article 122a CRD, which was implemented in the UK in BIPRU s9.15 and which entered into force on 1 January 2011 for newly securitised products. ${ }^{31}$ To ensure its adherence also by non-EU originators, the burden of proof lies with the investing credit institution. It has to ensure that the originator discloses the relevant information regarding compliance with the retention requirement and non-hedging of the retained exposure. $^{32}$ The rule states that a credit institution is only to invest in

\footnotetext{
${ }^{26} \mathrm{Ng}$ (n 10) 266; see also: Committee of European Banking Supervisors (CEBS), 'Impact Assessment' on Art. 122a (30 October 2009) para 3, available at http://eba.europa.eu/documents/10180/16106/CEBS-2009-232-final-\%28ImpactAssessment---Retention-in-Securitisation\%29.pdf.

${ }^{27}$ Committee of European Banking Supervisors (CEBS), 'Call for a technical advice on the effectiveness of a minimum retention requirement for securitisation' (30 October 2009) para 81, available at http://eba.europa.eu/documents/10180/16106/Advice.pdf.

${ }^{28}$ John Kiff and Michael Kisser, 'Asset Securitization and Optimal Retention' (2010) IMF Working Paper 10/74, 3, available at http://ssrn.com/abstract=1578672.

${ }^{29}$ CEBS advice on risk retention, paras 1-2.

${ }^{30} \mathrm{Ng}$ (n 10) 266.

${ }^{31}$ ibid; grandfathering rules apply for existing securitisations until 31 December 2014; see also CRR proposal, art 394(1).

${ }^{32}$ BIPRU, s9.15.5; $\mathrm{Ng}$ (n 30) 267.
} 
securitised products if either the originator, the sponsor or the original lender (hereafter: originator) has retained a net economic interest of not less than five percent in the securitised assets on an on-going basis. Thereby, it is important that the retention rule will only apply if the investor is a credit institution. If the investors were non-regulated entities such as hedge funds, then the retention requirement would not have to be adhered to by originators.

While the mandatory nature and the five percent level of the retention requirements are new, originators already retained an interest on a voluntary basis in the form of credit enhancement before the GFC. ${ }^{33}$ They chose to expose themselves to varying degrees to the first loss pieces by way of holding the equity tranche (ie subordinating themselves to more senior tranches) with the aim of enhancing the credit rating of more senior tranches and to attract more investors. ${ }^{34}$ Hence, in light of originators already having undertaken retention before the GFC voluntarily, the actual effect of the new rule will strongly depend on the adequacy of the chosen level. If it is not higher than the previously voluntary level chosen, the effect may be smaller than envisaged.

In the CRD a one-size-fits-all approach was chosen by setting the level to five percent, which will have to be maintained on an on-going basis. However, little evidence exists on the adequacy of this level. ${ }^{35}$ Based on limited availability and quality of data, CEBS

(now EBA) identified that in the UK retention levels varied from $1 \%$ to $14.4 \%$ depending on the type of underlying assets. According to a wholesale banker, levels even amounted to up to $25 \%$ due to investor pressure $;^{36}$ here, the new requirement had only an effect on a few originators. In Continental Europe, CEBS identified that credit institutions were retaining between $0.8 \%$ and $4.6 \%$ of first loss tranches $;{ }^{37}$ here, the prescribed level of five percent would potentially be more effective. CEBS refrained from suggesting to raise the incentive level above five percent as no evidence would exist that a higher level would align the interests better. In contrast, to circumvent the rule originators could either internalise the increased costs accompanying the higher retention level and transfer it to the investors, or reduce the overall

\footnotetext{
${ }^{33}$ Kurt Eggert, 'The Great Collapse: How Securitization Caused the Subprime Meltdown' (2009) 41(4) ConnLRev 1257, 1307.

${ }^{34}$ CEBS advice on risk retention, para 8.

${ }^{35}$ Ibid, para 82.

${ }^{36}$ Interview with a banker, Lloyds TSB Bank plc (London, 31 August 2012).

${ }^{37}$ CEBS art 122a impact assessment, paras 6-15.
} 
level of securitisation. ${ }^{38}$ Hence, CEBS points out that the effectiveness of the skin-in-the-game approach is improved by accompanying it with other measures such as disclosure and due diligence requirements than by increasing the retention level. ${ }^{39}$

\section{Retention methods}

To retain the five percent the legislator provides a choice of four methods: holding five percent of each tranche (vertical slice), holding five percent of the nominal value of the exposure in case of a revolving structure, holding a random selection of exposures, or holding five percent of the equity tranche. ${ }^{40}$ The chosen method can neither be changed during the life of the securitisation nor can be applied cumulatively. ${ }^{41}$

The precise effect of each of the four methods is yet unclear. CEBS argues that no method prevails over the other as none is short of drawbacks depending on the situation run through. ${ }^{42}$ The scholarly debate affirms this perception. Fender and Mitchell analyse the screening effects on the originator of the vertical slice, the equity tranche and the mezzanine tranche method. They conclude that if an economic downturn is very likely the equity tranche would lose its screening effect as the originator knew it lost its retained interest in any case. Instead, they suggest that holding the mezzanine tranche would ensure proper due diligence even in an economic 'low state' even though it would be less effective in the 'high state' of the economy. ${ }^{43}$ On the other hand, Kiff and Kisser disagree based on their model and argue that holding the equity tranche would result in the greatest screening efforts by the originator, provided that the originator could decide both on screening efforts and the retention level. This is due to the fact that Fender's and Mitchell's findings were dependent on economic conditions: the loan pool's quality, its default probability and the thickness of the retained tranche. Moreover, Kiff and Kisser note that the originator would

\footnotetext{
${ }^{38}$ CEBS advice on risk retention, para 81-87.

${ }^{39}$ Ibid, para 7; a similar view is taken by Ingo Fender and Janet Mitchell, 'Incentives and Tranche Retention in Securitisation: a Screening Model' (2009) BIS Working Papers No. 289, 34, available at http://ssrn.com/abstract=1481663.

${ }^{40}$ BIPRU s9.15.4; CRD, art 122a(1).

${ }^{41}$ Committee of European Banking Supervisors, 'Guidelines to Article 122a of the Capital Requirements Directive' (31 December 2010) para. 32, available at http://eba.europa.eu/documents/10180/106202/Guidelines.pdf.

${ }^{42}$ CEBS advice on risk retention, para 10.

${ }^{43}$ Ingo Fender and Janet Mitchell, 'Incentives and Tranche Retention in Securitisation: a Screening Model' (2009) BIS Working Papers No. 289, 19, 33, available at http://ssrn.com/abstract=1481663; CEBS art 122a impact assessment, paras 28-30.
} 
generally not hold the equity tranche voluntarily as it would come along with greater capital costs. ${ }^{44}$ Instead, it would choose the least costly method, ${ }^{45}$ or if pressurised by sophisticated investors the vertical slice as it would guarantee the greatest skin-in-the-game in all economic situations. ${ }^{46}$ As an alternative to the four methods available, the L-shaped method as a mixture of holding the mezzanine and equity tranche is currently being discussed by regulators. ${ }^{47}$ CEBS considers it to be the second best solution but delays its implementation to the point in time once a more thorough assessment will be conducted. ${ }^{48}$ As a result, each method's precise effectiveness of incentivising screening is yet unclear. Originators will choose the overall least costly method and exploit arbitrage opportunities. Therefore, the methodologies will need to be reassessed as soon as sufficient data exists in order to identify which retention method meets the objective best.

\section{Optimal retention level and method remain to be found}

Consequently, the OTD-model and the total risk transfer by originators resulted in improper screening of the underlying assets to the detriment of investors. In contrast, investors were not given sufficient information so as to assess the asset portfolio themselves. It is suggested that this misalignment of interests may be rectified by means of the five percent retention requirement, which aims at incentivising the originator into proper screening and underwriting. The originator has to disclose details on its retention method chosen, thereby enabling the investor to verify whether the requirements are met as otherwise he would not be allowed to invest. However, both regulators and scholars remain equivocal about which retention method is most effective as research indicates that it varies according to the economic climate and the asset types. Yet, sophisticated investors tend to require vertical slice retention. In turn, this would explain why so much discretion is left to the originator, who can be expected to choose the cheapest method and take advantage of arbitrage opportunities. Moreover, it can only be concluded that the five percent level is at best an approximation. Overall, it seems to depend on the market and types of financial institution whether the level is lower or higher than the previous

\footnotetext{
${ }^{44} \operatorname{Kiff}(\mathrm{n} 28) 28 \mathrm{f}$.

${ }^{45}$ CEBS art 122a impact assessment, para 27.

${ }^{46}$ Lloyds banker interview (n 36).

${ }^{47}$ CEBS art 122a impact assessment, para 32.

${ }^{48}$ Ibid; Metin Kaptan, 'On the Optimal Design of Risk Retention in Securitisation' (2011) 16, available at $\mathrm{http}: / / \mathrm{ssrn} . \mathrm{com} / \mathrm{abstract}=1923075$, arguing the opposite: high retention levels for highly-ranked tranches and low retention levels for low-ranked tranches.
} 
voluntary retention levels; no evidence or research is available justifying that it would be the optimal level. The failure to distinguish between the riskiness of the different underlying assets also provides arbitrage opportunities. ${ }^{49}$ Therefore, I am of the opinion that the retention requirement is likely to be the first step in the right direction but that adjustments will have to be taken. Both European and national regulators should undertake an effectiveness assessments of the current rules as soon as sufficient data is available so as to minimise arbitrage opportunities and to ensure that the retention rules indeed align the originators' and investors' interests. So far, it is only certain that the originators' risk transfer and diversification opportunities are restrained thereby. Another moral hazard problem lies in the fact that investors become overconfident in the retention requirement's effectiveness and stop investing resources in their own due diligence. The consequences we do not know yet about due to insufficient knowledge might even be worse.

\section{Capital Requirements}

The GFC revealed that credit institutions were undercapitalised to meet all of their going concern liabilities. This was also the case for (re)securitisation exposures. The original idea of securitisation was to diversify risk for financial institutions by transferring it to non-banking investors and at the same time reduce costly bank capital. However, in practice risk exposures were not diversified but either sold to other banks' proprietary trading desks, retained via derivative contracts, used as collateral or resecuritised. ${ }^{50}$ Resecuritisation proved to be especially prone to disguise risk and to cause underlying correlation. ${ }^{51}$ To ensure that risk exposures did not result in high capital requirements in banking books, exposures were hold in the trading book. Against the latter, less capital had to be hold according to Basel II on grounds that its assets would be more liquid and could easily be unwound. ${ }^{52}$ However, the crisis revealed that this was not the case. In addition, overreliance on Value-at-Risk (VaR), used to estimate the probability of a

\footnotetext{
${ }^{49}$ CEBS art 122a impact assessment, para 25.

${ }^{50}$ Financial Services Authority, 'The Turner Review, A regulatory response to the global banking crisis' (London, March 2009) 15f, available at http://www.fsa.gov.uk/pubs/other/turner_review.pdf.

${ }^{51}$ Steven L Schwarcz, 'Regulating Complexity in Financial Markets' (2009) 87(2) WashULRev 211, 223; Financial Services Authority, 'Strengthening Capital Standards 3' (Consultation Paper, CP09/29, December 2009) para 5.51 (FSA CP09/29).

${ }^{52}$ David Ramos Muñoz, The Law of Transnational Securitization (OUP 2010) para 7.211.
} 
specific loss level, failed to capture low probability high loss events. ${ }^{53}$ Thus, resecuritisation proved to be more risky and required more liquidity. The difference in capital charges between trading and banking book were used to circumvent the capital rules and gave arbitrage opportunities to financial institutions.

\section{Defining and risk-weighting resecuritisation exposures}

Sophisticated products such as resecuritisations were in need of more liquidity than originally expected. ${ }^{54}$ As credit losses became more correlated in cyclical downturns, resecuritisations were more affected than securitisations due to their inherent structure: their underlying assets are generally composed of low-rated (e.g. BBB) securitisation exposures. To address this increase in risk, BCBS suggested discouraging the issuance of complex structures by increasing the bank capital retained for complex products. ${ }^{55}$ However, hitherto neither the Basel II Framework nor national laws distinguished between the different types of complex structured products, i.e. securitisation and resecuritisation.

Before discussing the new and stricter rules for resecuritisation exposures, the limits of capital requirements should briefly be displayed. Kashyap et al highlight the limits of what capital requirements can do. Apart from that they will be burdensome on the banks' business by increasing costs, they will also increase incentives for regulatory arbitrage as long as there is financial innovation. ${ }^{56}$ Ayadi has questioned the overall appropriateness of the prescribed risk-weights and whether they would not strongly be politically driven.$^{57}$ For instance, Basel I assigned $100 \%$ for all ABS except RMBS, which were risk-weighted with 50\%. Hence, it should be born in mind that also this means of regulatory intervention has its limits.

In light of the emerging necessity to distinguish between the two types of securitisation from a capital regulatory point of view, CRD3 has introduced in line with Basel III a new definition for resecuritisation. In

\footnotetext{
${ }^{53}$ FSA Turner Review, 58.

${ }^{54}$ Peter Went, 'Basel III Accord: Where do we go from here?' (2010) 6, available at http://ssrn.com/abstract $=1693622$.

55 Bank of International Settlement, 'BCBS the Joint Forum, Report on asset securitisation incentives' (BIS, July 2011), 58 (BIS securitisation incentives).

${ }^{56}$ Anil K Kashyap, Raghuram G Rajan and Jreemy C Stein, 'Rethinking Capital Regulation' (Symposium by Federal Reserve Bank of Kansas City on 'Maintaining Stability in a Changing Financial System', Jackson Hole, 21-23 August 2008) 23, 26.

${ }^{57}$ Rym Ayadi, Emrah Arbak and Willem P de Groen, 'Implementing Basel III in Europe: Diagnosis and avenues for improvement' (6/2012) CEPS Policy Brief no. 275, 4, available at http://ssrn.com/abstract $=2098932$.
} 
essence, it constitutes a securitisation of a securitised tranche, such as a CDO of ABS. The legislative scope is very wide, as no materiality threshold exists. It suffices that only one underlying exposure constitutes a securitisation exposure. ${ }^{58}$ The definition has retroactive effect and hence applies to existing resecuritisation positions. ${ }^{59}$ Owing to the wide scope, advisors of credit institutions have emphasised the necessity to review their existing securitisation exposures of their clients to ensure that they are not affected negligently by the higher capital requirements applicable to resecuritisation. ${ }^{60}$

Essentially, the capital requirements for securitisation exposures are risksensitive to the exposure's default probability. The default risk is expressed in a credit quality rating of the secured product, which can either be determined by an external credit assessment institution, such as a CRA, or internally depending on the approach adopted by the credit institution. Each credit rating, referred to as credit quality step, matches a risk-weight percentage in order to reflect the exposure's probability of default. ${ }^{61}$ Concerning the number of credit quality steps, the internal rating based (IRB) approach is more nuanced than the long-term standardised approach (STA). In line with the BCBS approach, CRD3 increases the risk-weight for resecuritisation exposures. Under the STA, a risk-weight of $40 \%$ for AAA to AA- rated products to up to $650 \%$ for BB+ to BB- (against $20 \%$ and $350 \%$ respectively for securitisation) is applied. ${ }^{62} \mathrm{~A}$ similar increase is made for banks using the IRB approach though it is a bit more favourable. For unrated products such as first-loss pieces nothing has changed. The capital amount is to equal the exposure, reflecting a risk-weight of $1,250 \%$ (called deduction level). Hence, the legislator has discouraged but not prohibited the issuance of complex resecuritised products by increasing their risk-weights and ultimately the capital to be retained for those exposures. This has contributed to a decrease in the issuance of resecuritised products. ${ }^{63}$

\footnotetext{
${ }^{58}$ CRD, art 4(40a); Financial Services Authority, 'Strengthening Capital Standards 3, further consultation on CRD3' (Consultation Paper, CP 11/09, March 2011) para 3.6ff (FSA CP11/09).

${ }^{59}$ FSA CP11/09, para 3.18.

${ }^{60}$ Morrison \& Foerster LLP, 'CRD3 Changes to Trading Book, Resecuritisations and Securitisations Disclosure' (2010) December News Bulletin, 2, available at http:/www.mofo.com/files/Uploads/Images/2101123-CRD3-Changes-to-Trading-

Book.pdf.

${ }^{61}$ Ramos Muñoz (n 52) 335f.

${ }^{62}$ BIPRU s9.11.2R; $\mathrm{Ng}$ (n 30) 271.

${ }^{63}$ Lloyds banker interview (n 36).
} 


\section{Trading book adjustments}

The former trading book treatment originated from the 1990s in the Basel I amendments and was later taken over to the Basel II Framework. ${ }^{64}$ Thereunder, credit institutions had to retain a lower capital level against their risk exposures than in their banking book as those exposures were allegedly more liquid and to be unwound more easily. The market risk was considered to be reasonably lower, also for securitisation positions. Through VaR, the maximum overnight loss at a given confidence and probability level could be calculated. This helped credit institutions to estimate the capital level required which generally would be lower. However, the VaR model was not immune against model risk. It failed to capture 'high loss low probability' events which according to the model should not have occurred anytime soon. However, they did and the capital level proved to be insufficient. (Re)securitisation exposures were especially affected thereby. In the downward economical climate securitisation exposures proved to be unwound less easily than expected. In combination with the liquidity shortages, it was found that those positions should have been held in the banking book instead.

To remedy that financial institutions held securitisation positions in the trading book instead of the banking book and thereby attracted lower capital requirements, CRD3 has introduced that the capital requirements for securitisation positions in the trading book are equal to the banking book. ${ }^{65}$ Model risk will be eliminated through the introduction of such standardised /fixed capital charges. ${ }^{66}$ More importantly, it eliminates the basis for capital arbitrage. Hence, by equalising the capital charges for securitisation positions in the trading and banking book, the legislator adopts resolute measures to remedy previous arbitrage opportunities. In turn, it will result in a reduction of business activities or in the increase of capital levels for credit institutions.

\section{Reduction of overall securitisation level}

The broad definition of resecuritisation in combination with the higher riskweights has at least contributed to an overall reduction in origination of

\footnotetext{
${ }^{64}$ FSA Turner Review, 58.

${ }^{65}$ Commission, 'Accompanying document to the Proposal for a Directive of the European Parliament and the Council amending Capital Requirements Directive on trading book, securitization issues and remuneration policies' (Impact Assessment) SEC(2009) 974 final, 14f (CRD3 impact assessment); Morrison (n 60) 3.

${ }^{66} \mathrm{CRD} 3$, recital 34.
} 
resecuritised products. As the precise effects are difficult to measure yet, the reduction can also be the result of investors realising that resecuritised products such as CDS are little profitable in the long term. Nevertheless, the basis of the increased risk-weight levels should be ascertained. BCBS bases them upon empirical evidence but fails to give more detailed information. ${ }^{67}$ It remains unclear by how much BCBS aims to discourage the issuance of complex structures. It can only be held that risk-weights were not set as high as to totally discourage resecuritisation issuance as therefore levels would be to set at deduction level. ${ }^{68}$

However, the original overall minimum capital requirements hold by banks were the result of negotiations instead of scientific calculations and in the aftermath of the crisis proved to be too low. Given the FSA attests that no optimal answer exists so far, ${ }^{69}$ the author concludes that the increased risk-weights are probably not optimal either. If that were the case, both Ayudi and Kashyap would be right to point out the potential for arbitrage opportunities, ${ }^{70}$ which could undermine the effectiveness of the system in the long run. In addition, the overall level of securitisation including classic securitisations is likely to reduce given that more capital will have to be hold against securitisation positions in the trading book as well as a result of the retention requirements. In times of capital shortages, it is unlikely that credit institutions are in a position to increase their capital levels. Thus, the regulator should closely monitor the impacts of the adopted measures so as to ensure that all consequences are anticipated. However, currently the impression remains that not all side effects and undesirable costs are known.

\section{Disclosure, TRANSPARENCY AND STANDARDISATION}

The reasons for misalignment of interests are not solely to be found by the originators. Both retail and sophisticated investors also failed to take informed investment decisions with the effect of their risk exposure not commiserating to their set risk profile. ${ }^{71}$ Two explanations are available for this: either investors have not been in a position to assess the originator's underwriting standards due to insufficient information, or they have acted

${ }^{67}$ Bank of International Settlement, 'BCBS Consultative Document, Proposed enhancements to the Basel II framework' (BIS, January 2009), 4.

${ }^{68}$ CRD3 impact assessment, 26.

${ }^{69}$ FSA Turner Review, 55.

${ }^{70}$ Ayadi (n 57) 4f; Kashyap (n 56) 23, 26.

${ }^{71}$ Eggert (n 33) 1303f. 
irrationally and chosen not to assess the published information due to its complexity and information overload. Yet, higher returns of securitised products have let investors turn a blind eye on increased complexity. They have over-relied on credit ratings ${ }^{72}$ and on alleged safety structures such as credit enhancement ${ }^{73}$ and became subject to heuristic behaviour. ${ }^{74}$

\section{Insufficient disclosure}

Hitherto, regulators have addressed information asymmetry mainly by requiring full disclosure, ${ }^{75}$ which has been justified on grounds of the efficient capital market hypothesis (ECMH) as it was developed by Gilson and Kraakman. A stock's price will reflect the true value of the company if rational investors have available all necessary information about the company in order to incorporate it into the stock's price. However, the effectiveness of the ECMH on securitised markets of strong innovative forces is disputed, as it was recognised by Gilson and Kraakman already. ${ }^{76}$ Schwarcz reaffirms that the ECMH does not apply to (private) debt markets as they are generally private in nature and no active trading environment exists for price finding. ${ }^{77}$ Taking a closer look at the model, two of its assumptions were not met in the securitisation market: investors did not always have access to all necessary information for proper price and risk evaluation; ${ }^{78}$ and they acted irrationally. Thus, from an academic perspective, it is questionable whether full disclosure in the securitisation market will really put the investor in a position in which he is able to assess the originator's screening efforts fully.

Nevertheless, legislators adhere to the full disclosure principle. Additional disclosure and screening requirements are imposed on both originators and investors. Originators have to disclose not only their retention level (Art.122a sentence 1 CRD) but also provide investors with 'all materially relevant [loan-level] data' concerning the underlying

\footnotetext{
72 International Organisation of Securities Commissions (IOSCO), Technical Committee, 'Unregulated Financial Markets and Products' (Final Report, September 2009), 16.

${ }^{73}$ Eggert (n 33) 1303-1307.

${ }^{74}$ Steven L Schwarcz, 'Regulating Complexity in Financial Markets' (2009) 87(2) WashULRev 211, 222.

${ }^{75}$ Schwarcz (n 5) 1117.

${ }^{76}$ Ronald J Gilson and Reinier H Kraakman, 'The Mechanisms of Market Efficiency' (1984) 70 VaLRev 549, 568, 585, 615-6.

${ }^{77}$ Schwarcz (n 5) 1116.

${ }^{78}$ Eggert (n 33) 1306; Emilios Avgouleas, 'Financial Regulation, Behavioural Finance, and the Global Financial Crisis: In Search of a New Regulatory Model' (2009) 9 JCLS 23,45 .
} 
exposures (sentence 2) ${ }^{79}$ This includes all information to enable them to assess the credit quality and performance, the cash flows and collateral supporting the exposure as well as to conduct stress tests thereof (hereafter: investor due diligence). Whereas it puts investors in a position to fulfil their role in theory, it is not clear whether they will perform their entrusted role also in practice or persist with heuristic behaviour.

\section{Information overload and standardisation}

Paredes elaborates on the limits of the regulatory full disclosure paradigm and points out the likelihood of investors behaving irrationally on the ground of 'limited cognitive abilities to process information'. ${ }^{80}$ Full disclosure led to an overload of information, which backfired at its primary objective. Instead of empowering investors, they addressed the growing amount of information and its inherent complexity with heuristics and took over-simplified decisions. ${ }^{81}$ This idea is supported by Avgouleas who argues that proper risk evaluation necessitated proper financial sophistication. ${ }^{82}$ Paredes suggests in general that information overload needed to be considered more strongly in financial regulation; ${ }^{83}$ and in particular, either to scale back on mandatory disclosure or to improve the comparability, evaluation and standardisation of information for investors. ${ }^{84}$ Schwarcz considers disclosure by institutions to have been extensive enough. He argues that disclosure by financial institutions such as in prospectuses always complied with respective regulation. As it was so extensive and complex institutions either failed to staff the necessary expertise or took a short cut by not assessing the information properly and instead reverted to credit rating reliance. ${ }^{85}$ Moreover, wholesale banks have already started to disclose loan-level data but argue that investors refrain from looking at it. ${ }^{86}$ Thus, scholars and markets attach greater importance to the limited effect of more disclosure. Investors either would fail to adequately analyse it or be overburdened thereby.

\footnotetext{
${ }^{79}$ See also CRR proposal, art 398.

${ }^{80}$ Troy Paredes, 'Blinded by the Light: Information Overload and its Consequences for Securities Regulation' (2003) 81 WashULQ 417, 444.

${ }^{81}$ Ibid.

${ }^{82}$ Avgouleas (n 78) 45.

${ }^{83}$ Paredes (n 80), 484.

${ }^{84}$ Ibid, 474ff.

${ }^{85}$ Schwarcz (n 5) 1114f; see part IV on personal conflict of interest of credit rating agencies.

${ }^{86}$ Lloyds banker interview (n 36).
} 
Nonetheless, European legislation aims at the prevention of the investor turning a blind eye on the disclosed information and of over-relying on credit ratings. Information overload and the complexity issue are addressed to a lesser extent by it. An investing credit institution has to demonstrate to the PRA that it has a thorough understanding of each of its individual securitisation positions and has procedures in place to assess the commensurateness with its own risk profile (BIPRU s9.15.11-13). Regular stress testing (BIPRU s9.15.12) as well as on-going performance monitoring of exemplarily specified information, including of loan level data, are required (BIPRU s9.15.14f). ${ }^{87}$

While legislation has not addressed the growing complexity of information yet, both academics ${ }^{88}$ and public institutions ${ }^{89}$ have called for greater standardisation of information to enhance comparability and minimise complexity. Initiatives by the European Central Bank (ECB) and the Bank of England (BoE) exist. Both institutions have developed eligibility criteria for each securitisation asset class with a twofold purpose: to provide a transparent framework determining which assets will be permitted as collateral in their internal lending operations; and to boost investor confidence in the securitisation market by enhancing standardisation and transparency. Originators and sponsors are asked to disclose loan-level data in a standardised format per asset class for which templates have been developed, ${ }^{90}$ containing around 180 to 240 questions. This information is to be made publicly and freely available so as to facilitate investor due diligence. While the ECB has supported the development of a single private loan-level data repository (European DataWarehouse $\mathrm{GmbH}$ ) ${ }^{91}$, the BoE has decided not to mandate such an infrastructure but to ask merely for the information to be made publicly available. According to market forces, investors are already requiring originators to adhere to the Central Banks' templates as this would ultimately add liquidity for trading purposes. ${ }^{92}$ Other

\footnotetext{
${ }^{87} \mathrm{CRD}$, art 122a (4)-(5); see also CRR proposal, art 395 and 396, which would impose additional risk weights in case of non-compliance due to negligence or omission.

${ }^{88}$ Schwarcz (n 74) 241; Paredes (n 80), 474ff.

${ }^{89}$ International Organisation of Securities Commissions, 'Global Developments in Securitization Regulation' (Consultation Report, CR09/12, June 2012), 16f; BIS securitisation incentives, 22.

${ }^{90}$ BoE templates, available at

http://www.bankofengland.co.uk/markets/Pages/money/eligiblecollateral.aspx; ECB templates, available at http://www.ecb.europa.eu/mopo/assets/loanlevel/transmission/html/index.en.html.

${ }^{91}$ European DataWarehouse, available at http://www.eurodw.eu/.

${ }^{92}$ Lloyds banker interview (n 36).
} 
more recent market-led initiatives have been the Dutch Securitisation Standard for RMBS, developed by the Dutch Securitisation Association, ${ }^{93}$ and the introduction of the PCS Label for ABS for meeting defined eligibility criteria developed by the UK based Prime Collateralised Securities. ${ }^{94}$ Hence, it remains positive that standardisation initiatives have gained momentum, but whether the Central Banks' or the market approaches will prevail still remains to be seen.

\section{Complexity of information remains a major challenge}

The EU and respective UK legislation envisage to improve the foundation for a disclosure and transparency regime. By prescribing both originators to disclose all relevant data to investors and investors to engage in investor due diligence based on the disclosed data, the legislator adheres to the full disclosure regime and obliges investors to use it. However, it does not address the potential information overload problem of investors. Instead, legislators assumed that investors negligently did not assess information but over-relied on credit ratings. Nevertheless, thorough disclosure requirements are important in order to put investors in the position to perform its designated role properly in the first place: approach loan-level data critically, require premiums for uncertainty, ${ }^{95}$ and quantify the risks accordingly. After investors and scholars have called for more standardisation, the BoE and ECB were the first by having introduced respective templates to request information in a standardised format. Since then, market-led initiatives have followed in the Netherlands and UK emphasising that there is a clear demand to structure the disclosed information and counter regulatory initiatives. From my point of view, market-led initiatives constitute the best means to ensure that only relevant information is disclosed - avoiding information overload and minimising complexity - which in turn empowers sophisticated investors to regain control and align interests. It would also ensure that standards are internationally convergent, coordinated and amended timely taking into account the fact that the securitisation market is highly cross-jurisdictional. At the same time, it would guarantee that a sufficient degree of efficiency through standardisation is reached in order to strike a balance with regard to enhanced disclosure and costs.

\footnotetext{
${ }^{93}$ Dutch Securitisation Association, available at http://www.dutchsecuritisation.nl.

${ }^{94}$ Prime Collateralised Securities, available at $\mathrm{http}$ ://pcsmarket.org/.

${ }^{95}$ Schwarcz (n 74) 262f.
} 


\section{E. Credit Rating Agencies}

In the GFC several imperfections in the credit rating agencies' (CRAs) system were fortified, which jeopardised their role to provide information symmetry in the securitisation market. In the case of subprime RMBS and CDO market, CRAs failed to assess the creditworthiness of the underlying assets adequately, resulting in investment grade rated securities to default on a large scale and in delayed downgrading. ${ }^{96}$ The causes can be attributed to CRAs themselves, investors and financial regulation. This is generally considered to be the result of a mixture of problems: disproportionate regulatory reliance on credit ratings, organisational and personal conflict of interest (COI) within CRAs, and growing complexity of the securitised products resulting from continuous innovation and resecuritisation ${ }^{97}$ alongside with outdated methodologies and short-sighted historical data.

\section{Regulatory reliance}

For over a century, CRAs have been unregulated in Europe and the UK in light of constraining market and reputational forces. ${ }^{98}$ Only in 2004, IOSCO established a non-binding code of conduct. ${ }^{99}$ Today, there is a dominance of three US CRAs with no significant European or Asian competitor. It is the result not only of decades of consolidation, but also of a respective regulatory environment. The use of credit ratings for calculating capital requirements became mandatory for credit institutions since the 1988 Basel Accord. Only ratings of duly registered CRAs could be used; but the registration system was non-transparent and imposed high entry barriers. ${ }^{100}$ This regulatory reliance, it is argued, has given ratings the status of a public $\operatorname{good}^{101}$ or even of 'force of law', ${ }^{102}$ despite ratings being nothing but

\footnotetext{
${ }^{96}$ Kristina St. Charles, 'Regulatory Imperialism: The Worldwide Export of European Regulatory Principles on Credit Rating Agencies' (2010) 18(2) Minnesota JIntlL 399, 406.

${ }^{97}$ Schwarcz (n 74) 223; Richard Barley, "Ability to track risk has shrunk "forever" Moody's' Reuters (online 6 January 2008), available at http://www.reuters.com/article/2008/01/07/moodys-risk-idUSL0455354520080107.

${ }^{98}$ White (n 24) 2.

${ }^{99}$ International Organisation of Securities Commissions, 'Code of Conduct Fundamentals for Credit Rating Agencies' (December 2004).

${ }^{100}$ White (n 24) 4.

${ }^{101}$ Schwarcz (n 5) $1120 f$.

${ }^{102}$ White (n 24) 3, 5.
} 
opinions, or arguable 'fact-based opinions', protected by the first amendment of the US Constitution. ${ }^{103}$

As a result, scholars not only call for less regulatory reliance on CRAs but also for less regulatory intervention to address the system's shortcomings. Schwarcz opposes more regulation on the basis of the limited abilities of public institutions and governmental certification. ${ }^{104}$ White favours the abolition of the non-transparent registration system to reduce entry barriers and stimulate competition. ${ }^{105}$ Advisors and credit institutions, constituting alternative 'sources of creditworthiness', should be relied upon by increasing their accountability. In turn, those measures would foster rating innovation of new technologies and methodologies. ${ }^{106}$ Furthermore, detailed regulation would be counterproductive by giving investors a false sense of security in ratings. ${ }^{107}$

Nonetheless, EU legislators have pursued with regulation on grounds of the CRAs' failure to deliver quality ratings in time. ${ }^{108}$ While the UK regulator would favour principles-based regulation, also referred to as the 'outcomes-focused approach' by former FSA Chief Executive Sants, ${ }^{109}$ the European Institutions adopted a prescriptive Regulation (hereafter: CRA Regulation), based on the IOSCO code of conduct. ${ }^{110}$ Complementarily, they attempt to reduce regulatory reliance by increasing the duties of investing

${ }^{103}$ For the issue of legal effect of a (fact-based) opinion see: Abu Dhabi Commercial Bank v. Morgan Stanley (2012), opinion by S.A. Scheindlin, USD.J., 32ff.

${ }^{104}$ Steven L Schwarcz, 'Private Ordering of Public Markets: the Rating Agency Paradox' [2002] UIllLRev 1, 20.

${ }^{105}$ White (n 24) 7-8; in affirmation: Claire A Hill, 'Why did Rating Agencies do such a Bad Job Rating Subprime Securities?' (2010) Minnesota Legal Studies Research Paper 10-18, 20, available at http://ssrn.com/abstract $=1582539$.

${ }^{106}$ White (n 24) 7-8.

${ }^{107}$ Letter from Michel Madelain, COO of Moody's Investors Service Ltd. to Maria Valentza, Head of Securities Unit, DG Internal Market, European Commission (5 September 2008) 7, available at https://circabc.europa.eu/sd/d/d239c220-ed02-4432a418-eabb4eb812da/Moody__s.pdf.

${ }^{108}$ Council Regulation (EC) 1060/2009 of the European Parliament and of the Council of 16 September 2009 on credit rating agencies [2009] OJ L302/1, recital 10 (CRA Regulation).

${ }^{109}$ Harry McVea, 'Credit Rating Agencies, The Subprime Mortgage Debacle and Global Governance: the EU Strikes Back' (2010) 59 ICLQ 701, 717f, referring to Hector Sants, 'Delivering intensive supervision and credible deterrence' (Speech, The Reuters Newsmakers event, 12 March 2009), available at http://www.fsa.gov.uk/library/communication/speeches/2009/0312 hs.shtml.

${ }^{110}$ Council Regulation (EC) 1060/2009 of the European Parliament and of the Council of 16 September 2009 on credit rating agencies [2009] OJ L302/1 (CRA Regulation), entry into force: December 2010. 
financial institutions. CRD2 prescribes investing credit institutions to monitor the on-going performance of their securitisation exposures and thereby addresses their previous blind reliance on ratings. Failure to undertake a comprehensive due diligence will result in heavy capital penalties by means of risk-weights at deduction level. ${ }^{111}$ Thus, the current strategy of regulators is to continuously rely on CRAs, improve their internal structure and at the same time to increase the responsibilities of investing credit institutions. Concerns by scholars about imprudent regulatory reliance have not been effectively addressed yet. Only last year BCBS has proposed to reduce the 'mechanic reliance on external ratings' in its 2012 proposal for a revised securitisation framework. ${ }^{112}$ Whether institutional investors will live up to the prescribed standards remains also to be seen. After all, the rating business emerged since there was a strong demand of creditworthiness analysis in the first place.

\section{Conflict of Interests}

At the root of the CRAs' failure to adequately assess the creditworthiness of structured products is the conflict of interest (COI). The organisational COI arises as the issuer of the securities is also the purchaser of the rating, a known shortcoming of the change to the issuer-pays model (IPM) in the 1970s. ${ }^{113}$ The personal COI arose especially in the subprime market as the remuneration system of CRAs led their employees to overrate securities so as to realise short-term bonuses. ${ }^{114}$

According to Schwarcz's theory, the organisational COI is not a problem as long as CRAs do not 'misbehave'. ${ }^{115}$ Indeed, the problem has not manifested in the traditional and transparent bond market. ${ }^{116}$ Pursuant to his theory misbehaviour does not occur despite missing public accountability because "negative reputational consequences [... would] far outweigh the fee a rating agency [... would be able to] charge for providing that [favourable] rating." ${ }^{.117}$ However, the COI has outweighed the reputational constrain since on the one hand the high margins of the subprime market

${ }^{111} \mathrm{CRD}, \operatorname{art122a}(5)$.

${ }^{112}$ Bank for International Settlement, 'Revisions to the Basel Securitisation Framework' (Consultative document) December 2012, 5.

${ }^{113}$ White (n 24) 4f.

${ }^{114}$ Christoph Kumpan, 'Conflicts of Interest in Securitisation: Adjusting Incentives', (2009) 9 JCLS 261, 274.

${ }^{115}$ Steven L Schwarcz, 'Private Ordering of Public Markets: the Rating Agency Paradox' [2002] UIllLRev 1, 15.

${ }^{116}$ White (n 24) 6.

${ }^{117}$ Schwarcz (n 115) 18. 
caused dependency and put issuers in a strong bargaining position, and on the other hand the given ratings were hardly transparent and reproducible. ${ }^{118}$ Hence, White suggests reducing regulatory reliance to dilute their market power. ${ }^{119}$ Alternatively, Kumpan suggests holding part of the issuer's payment in escrow and to make full payment dependent on any subsequent rating adjustments, if they had been predictable. Similarly, it would work for remedying the personal COI. ${ }^{120}$

Under the CRA Regulation, the COI will continue to exist as CRAs can continue to adhere to the IPM. ${ }^{121}$ To minimise its effect, article 6 imposes the prescriptive obligation to avoid any COI affecting the issuance of credit ratings. Further detailed rules on organisational and operational requirements are laid out in Annex I section A and B. Article 7 addresses the personnel COI by prohibiting rating analysts from engaging in fee negotiations with the rated entity, by mandating gradual rotation between rating mandates and by requiring that their remuneration cannot be contingent on the fee paid by the rated entity. ${ }^{122}$ Hence, by refraining from prescribing a different business model, the European legislator has accepted the prevalence of the IPM and thus the COI. Its remedy is to impose prescriptive rules to mandate action or inaction instead of changing the business fundamentals and the origin of the problem.

\section{Complexity, innovation and outdated methodologies}

In the subprime market information asymmetry became wider than in the traditional bond market. The market's complexity increased due to constant financial innovation such as (multiple) resecuritisation in the form of CDOs. In 2008, Moody's recognised the limits of CRAs' ability to determine risk timely in this market and to maintain ongoing information symmetry. ${ }^{123}$ Furthermore, rating methodologies were outdated and based on insignificant short-term historical data especially for innovative and new products. Avgouleas describes this as the 'mega paradox': market participants

\footnotetext{
${ }^{118}$ White (n 24) 6.

${ }^{119}$ Ibid, 7.

${ }^{120}$ Kumpan (n 114) 285-288.

${ }^{121}$ See for detailed discussion Harry McVea, 'Credit Rating Agencies, The Subprime Mortgage Debacle and Global Governance: the EU Strikes Back' (2010) 59 ICLQ 701, $720 \mathrm{ff}$.

${ }^{122}$ CRA Regulation, art 7(2)-(5).

${ }^{123}$ Richard Barley, "Ability to track risk has shrunk "forever" -Moody's' Reuters (online 6 January 2008), available at http://www.reuters.com/article/2008/01/07/moodys-riskidUSL0455354520080107.
} 
including sophisticated investors, while being aware of those drawbacks, blindly relied on the ratings instead of reviewing them. ${ }^{124}$

Schwarcz attests that CRAs failed to detect the underlying correlation inherent in such complex securitised products, which were assumed to diversify risk. ${ }^{125}$ However, he argues that complexity and innovation cannot be prevented without affecting beneficial (re)securitisation transactions. ${ }^{126}$

The CRA Regulation addresses complexity in two ways. It prescribes information and rating standards ${ }^{127}$ and non-issuance of a rating in case of complexity or lack of sufficient data impeding the issuance of a quality rating. ${ }^{128}$ Complementary, investors are being empowered to better review the ratings by requiring CRAs to disclose their methodologies, models and key assumptions. ${ }^{129}$ In particular, additional disclosure requirements apply for structured products, such as disclosing due diligence efforts and stress scenarios simulations. ${ }^{130}$ Moreover, regulators consider it necessary to caution investors that they are dealing with structured products. CRAs will have to differentiate structured finance instruments ratings by the usage of another symbol. ${ }^{131}$ However, the measure has not gained much support both from scholars, CRAs and the UK authorities. They question the added value at highlighting the obvious ${ }^{132}$ point out the implementation difficulties in the absence of a clear definition of 'structured finance instruments', ${ }^{133}$ the disproportionate additional costs, ${ }^{134}$ and the resulting international

\footnotetext{
${ }^{124}$ Avgouleas (n 78) 30.

${ }^{125}$ Schwarcz (n 74) 223.

${ }^{126}$ Ibid.

${ }^{127}$ CRA Regulation, art 8(2)-(6).

${ }^{128}$ Ibid Annex I, s D(I)(4).

${ }^{129}$ CRA Regulation, art 8(1).

${ }^{130}$ CRD Regulation, recital 25, annex I, s D(II)(1)-(4); see also, McVea (n 121) 727.

${ }^{131}$ CRA Regulation, art 10(3); International Organisation of Securities Commissions, 'Code of Conduct Fundamentals for Credit Rating Agencies' (Revised, May 2008), para 3.5(b) (IOSCO CRA revised); Thomas MJ Möllers, 'Regulating Credit Rating Agencies: the new US and EU law - important steps or much ado about nothing?' (2009) 4(4) CMLR 477, 490.

${ }^{132}$ Edmund Parker and Miles Bake, 'Regulation of credit rating agencies in Europe' (2009) 24(7) JIBFL 401, 402ff.

${ }^{133}$ International Organisation of Securities Commissions, Technical Committee, 'A Review of Implementation of the IOSCO Code of Conduct Fundamentals for Credit Rating Agencies' (March 2009), 13; Letter by Moody's (Fn 107) 24.

${ }^{134}$ HM Treasury, FSA and Bank of England, 'Joint response by HM Treasury, the FSA and the Bank of England to the Commission consultation on a draft Directive/ Regulation on credit rating agencies (CRAs); and policy options to address the problem of excessive reliance on credit ratings' (5 September 2008) 20f, available at http://circa.europa.eu/Public/irc/markt/markt consultations/library?l=/financial_services/c redit_agencies/authorities/uk_ministrypdf/_EN_1.0_\&a=d.
} 
divergence caused in ratings. ${ }^{135}$ Hence, the EU legislator remedies the subprime market's complexity by setting minimum rating and information standards as well as by enabling investors through mandatory disclosure to reproduce and verify the basis of a given rating. Thereby, it does not reduce the CRA's importance but increases investors' responsibility.

\section{Are prescriptive rules really the best way to move forward?}

Thus, it can be held that European authorities have refrained from intervening radically in the CRA system. Regulatory reliance on CRAs has not been reduced, the issuer-pays-model from which the COI emanates will be maintained and innovation and complexity in the subprime market will continue to exist, increasing the probability of incorrect ratings. Instead, within the CRA Regulation a prescriptive rule set has been adopted, which aims at improving the CRAs' internal structures. Fundamental changes have been omitted. Two groups are intended to serve as a balance to the CRAs: investors and regulators. Investors are to monitor better their securitisation exposures and review the ratings, which is why methodologies and due diligence results are to be disclosed by CRAs. In the author's opinion, these are suitable means to establish checks and balances; by creating the basis for information equilibrium, investors will bear the responsibilities for their investments. However, it is questionable whether they can really do a better job given that CRAs will always have greater expertise as this is their core business. Regulators will have to supervise compliance of the descriptive rules by the CRAs. Here, the legislator should be cautious of regulatory over-reliance given the limited capacities of public institutions and their finite budgets. Determining that the issuance of a rating as not appropriate due to excessive complexity and insufficient historical data might constitute a very subjective element and thus difficult to prove. Moreover, legal accountability of CRAs has remained unchanged; any legislative change would have little effect as long as ratings are still recognised as opinions in the US. Changes would have to be made by the US courts or at an international level. As a result, the century of non-regulation of CRAs has come to an end. A new set of prescriptive rules has been adopted in hope of improving the CRAs' conduct. However, as fundamental structural deficiencies of the CRAs' system were not addressed, it remains to be seen whether the CRA Regulation is nothing more than a political declaration of intent to address the shortcomings.

${ }^{135}$ Charles (n 96) 446. 


\section{F. CONCLUSION}

This paper has analysed the regulatory developments in the structured market since the global financial crisis. The securitisation business grew significantly for two decades until an even stronger contraction in the summer of 2007. The products in question were at the heart of the crisis. Since then, six years have passed and legislators have adopted respective reforms to address the shortcomings in the securitisation market. The main problems were centred around four areas: first, misalignment of interests between investors and originators; second, inadequate capital rules failing to reflect the actual risk exposures; third, insufficient disclosure and information overload of investors; and fourth, CRAs failing to give quality ratings. These four shortcomings have been analysed separately throughout this paper. Although regulatory measures have been adopted to tackle each one of them, they have either been insufficient or caused new deficiencies to occur.

The interests of originators and investors started to misalign as a result of the replacement of the OTH-model with the OTD-model. Originators failed to maintain the same careful underwriting and screening standards. To reverse this trend and to increase incentives, the legislator introduced the retention rule, which is only to be complied with where investors constitute credit institutions. The requirements prescribe that sponsors or originators retain five percent of the underlying assets; this can be achieved through one of four methods, to be decided at the originator's discretion. However, the effectiveness of both criteria is not yet clear. In many circumstances, previous voluntary retention of at least equal size gives reason to question the effectiveness of rule. It was also held the level not to be more than an approximation in light of missing evidence as to its origin. This is similar for all four methods. Research indicates that their effectiveness varies depending on the economic climate, although investors tend to demand vertical slice retention of originators. If so many factors are still uncertain, the regulator is to be careful not to allow for arbitrage opportunities. Hence, the retention requirement might do nothing more than set minimum requirements and might actually have little effect in practice: skin-in-the-game has existed before and the rule's scope does not expand to investing entities such as hedge funds.

Previous capital requirements were little nuanced with respect to the complexity of securitised products and provided for arbitrage opportunities in accounting books. To remedy the former, the definition of resecuritisation 
was introduced. The scope of the definition is very broad so as to ensure that products with the smallest securitisation exposure and added complexity will also be covered. In addition, the risk-weights for those resecuritised products were increased so that credit institutions holding them on their books would have higher capital requirements. To avoid additional arbitrage opportunities between the trading and the banking books, the risk-weights were equalised for securitised exposures. However, there is no evidence of the origin or effectiveness of the increased risk-weight levels. The danger lies in them being too low, as was identified ex post in the case of the Basel I capital requirement levels. Nevertheless, it is probable that those reforms have already contributed to the decline in the issuance of resecuritised products. On the other hand, investors might also have realised that the CDOs' higher margins and low risk-weights have come at the price of high correlation in the low state of the economy. The levelling of the accounting books will have the effect of credit institutions reducing their overall securitisation exposures as higher capital charges will apply now. Likely, those exposures will be transferred to non-regulated entities and shadow-banks. As a result, regulatory capital reforms will have a chilling effect on the securitisation risk exposure held by financial institutions. An undesired consequence could be that the risks are transferred to non-regulated entities and shadow banks, where any level of monitoring will even be harder.

Legislators consider both originators not to have disclosed sufficient information and investors not to have analysed the disclosed information adequately. Instead, they are said to have relied blindly on credit ratings. On the other hand, scholars and markets argue that sufficient information was available but that the increased complexity led to information overload. This explains why the envisaged solutions partly differ. Legislators mandate originators to disclose additional loan-level data and investors to include the data in their investment decisions. Scholars promote further standardisation of existing disclosure to increase comparability and information assessment efficiency. Concerning standardisation, the original drive came from the ECB and BoE, which have each developed templates for their internal lending operations to receive standardised loan-level information. This information is made publicly available with the idea of reducing complexity and addressing the information overload faced by investors. If everything goes as planned, investors will make informed investment decisions. While such central bank measures seem to have been appreciated by investors, other market-led approaches have been taken in the Netherlands and the UK, 
which should facilitate international convergence. Given that standardisation has gained momentum, there is hope that the investors' information overload can be addressed effectively as benchmarking and quick information evaluation become possible.

The increasing complexity of innovative securitised products, internal conflict of interests and regulatory over-reliance led CRAs to give incorrect and biased credit ratings in the subprime market: substantial downgrading followed after the crisis broke out, especially in the US RMBS and CDO market. Still, the legislator has hardly reduced its reliance on CRAs, arguably on grounds of missing alternatives. Instead, it aims to tackle the CRAs' conflict of interests with prescriptive rules, which are to improve their internal governance structure. As an additional counterbalance, CRAs will have to disclose their rating methodologies, stress tests and data, so that investors can review the given ratings and, where applicable, question their validity. Whereas this seems to be a sound line of reasoning in theory, there may be some drawbacks. Investors will have little incentive and less expertise to review the ratings, given that they outsourced the rating service purposefully at the outset. Moreover, prescriptive rules demand supervision by regulators. In times of stringent budgets, the legislator should be cautious of not overburdening its regulators. Thus, the CRA Regulation might have a stronger political than regulatory effect. At best, the rules incentivise investors to stop relying blindly on credit ratings and to exercise their market power to restore the reputational restrain mechanism of CRAs, as it has worked well in the bond market.

The individual analyses of the measures adopted reveals that they barely succeed in remedying the addressed shortcoming. Whether these measures have the envisaged effect of improving the overall securitisation process is difficult to ascertain without seeing the effects of the reforms over time. Overall, the measures might end up not having the radical effect on the securitisation business hoped for by some politicians. However, this is not necessarily negative. The regulator is right to be cautious about interfering in complex markets, as is the case for securitisation. Many stakeholders are affected and the precise consequences of each regulatory measure are difficult to anticipate. Thus, determining fixed retention levels and riskweights without proper grounds justifying such levels can cause more harm than good, for instance by providing arbitrage opportunities. The risk of going beyond what is necessary should not be underestimated. The risk lies not only in preventing over-risky securitised products but also in closing down the whole securitisation market. The reason for this product's success 
over two decades is that it constituted a new funding method. As the European Commission affirms, sound securitisation structures can play an important role in providing financing to private markets, including to small and medium enterprises. ${ }^{136}$ Ultimately, securitisation could have potentially been not only the way in to, but also the way out of, the crisis.

The limits and negative externalities of regulation should also be borne in mind. Prescriptive laws, as are common in European regulation, are generally past-looking. This is adequate to prevent a repetition of the same crisis. Nevertheless, regulation rarely helps to anticipate the next crisis. It is a paradox that regulators are now regulating the securitisation market, which was the innovative side-effect of capital regulation in Basel I. This raises the question whether the currently enacted regulatory regime will lead to a future crisis. Another side-effect is that it unlikely achieves the deterrence of certain transactions. Instead, it might force business activities into unregulated markets. As the CRD, and thus most of the measures discussed, only apply to credit institutions, there is a real likelihood that transactions move to non-regulated entities and markets, such as shadow banks and hedge funds. Then, regulators will not even be in a position to monitor and intervene.

An alternative to imposing prescriptive rules could be for the regulator to support structural and market-led reforms. Rules need to be supervised, which raises the question of regulatory capacity in times of tight public budgets. This problem becomes especially apparent for the CRA Regulation. Here, a market-led solution might be more appropriate if it was able to restore the CRAs' reputational constraint, which has proven to work well in the bond market. The market should also be more engaged in standardisation setting of loan-level data. It would avoid useless information being disclosed, provide for flexibility, enhance the potential for effective benchmarking, and make standards more likely internationally convergent. Nonetheless, regulators or public institutions could give start-up aid in cases where initial set-up costs are too great.

To conclude, the adopted regulatory measures concerning securitised products have a rather limited effect overall. This seems to be especially the case for retention requirements and the rules concerning CRAs. However, this is not necessarily a serious problem if there are no foreseeable consequences following regulatory intervention. In this case, it is better for

${ }^{136}$ Commission, 'Long-Term Financing of the European Economy' (Green paper) $\operatorname{COM}(2013) 150$ final, 12. 
the regulator to be cautious and to avoid unnecessary compliance costs for market participants. Instead, market forces should be supported in developing adequate solutions, which, in turn, could be monitored to ensure that regulators are sufficiently informed and, therefore, able to intervene promptly when necessary. 